\title{
Recreational Demand for Fewa Lake: An Application of Travel Cost Method
}

\begin{abstract}
Arjun K. Thapa ${ }^{*}$
ABSTRACT

Economic valuation of non-market commodities like the recreational amenities provided by national parks, lakes, zoos and sanctuaries is complex and new in Nepal. In this study it is intended to analyze the recreational demand of Fewa Lake by using individual travel cost method. Fifty Nepali visitors were interviewed by administering close ended questionnaire schedule. Most of the respondents were urban unmarried males with secondary and above qualifications, earning a monthly income of around rupees ten thousand. The regression result shows cost of travelling, income, age, education and location as the major determinants of demand for Fewa Lake's recreational amenities. The consumer surplus was estimated to be Rs. 18.5 per Nepali visitor per trip. It can be inferred that a provision of entry fee along with quality enhancement would attract more visitors and generate revenue for this Lake.
\end{abstract}

Keywords: Consumer surplus, Fewa lake, recreational demand, travel cost method

\section{INTRODUCTION}

Increasingly, society is placing greater demands on nature based recreational amenities which have indirect market values. Pokhara Valley is one of the most beautiful places in the world, while Fewa Lake is its spectacular attraction where international and domestic tourists throng every year to be with its serene beauty to watch snow caped mountain range and enjoy boating. There is lack of proper management and proper fee system for utilization of amenities provided by the lake. Therefore, this study applies a travel cost method to measure the value of the lake.

The travel cost method was developed from a suggestion made by Harold Hotelling that empirically a demand schedule could be used to compute the total benefits produced to park visitors (Hotelling, 1947). On the basis of Hotelling's suggestions, Clawson (1959) then carried out some rigorous research using the developments contained in Hotelling's suggestions (Clawson, 1959).

Travel cost method is a primary non-market valuation method which estimates revealed preferences by comparing the travel costs of visitors or attendees to a particular (recreational) site or event (Shaw and Rogers,2005). Garrod and Willis (1999) put it that the method is primarily employed to estimate the demand or marginal valuation curve for recreational sites. Similarly, Sarker and Surry (1998), Sohngen et al. (1999), Shrestha et al. (2002), Blackwell (2007) and Anderson (2010) are just a few who have employed the ITCM.

\footnotetext{
* Mr. Thapa is Lecturer of Economics and Program Coordinator, School of Development and Social Engineering, Pokhara University. Email: yogirajarjun@gmail.com.
} 
Bell and Leeworthy (1990) evaluated the recreational demand by tourists for saltwater using the TCM and found out that the daily consumer surplus per visitor is about 34 US\$ (Bell \& Leeworthy, 1990). Similarly, Kaosa-ard, et al., (1995) using TCM to measure the Khao Yai National Park's use value and non-use value, found the average WTP for entrance fee is 22 baht per person and average WTP after some improvements was 44 baht per person (Kaosa-ard, et al.). Khan (2004) studying the recreational demand of Margalla Hills Park, suggested a park entrance fee of Rs. 20 per person could raise Rs. 11 million revenues annually for park management and improvement.

This study intends to identify the major factors that determine the recreational demand of Fewa Lake among Nepali respondents and explore their willingness to pay for improved lake condition.

\section{DATA AND METHODS}

In this study individual visitors were chosen as respondents for interviews. "Visitors" were defined as those Nepalese individuals who travelled to Fewa Lake for the purpose of recreation. A closed ended questionnaire schedule to be filled in by enumerators was surveyed for a week at the shore facing Tal Barahi Temple at Lakeside during November 2012. It is estimated that about a quarter of a million foreign tourists visit Pokhara but there are no proper accounts of internal tourists. Constrained by funding, only 50 Nepali respondents were sampled by visiting the above site over a week (about 7 persons per day).

In order to model the travel cost function, it has been followed the Freeman (1993) and assume that the individual's utility depends on the number of visits to the Fewa Lake, the quality of the Lake, and the quantity of the numeraire. The individual solves the following utility maximizing problem:

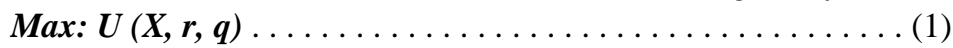

Subject to the twin constraints of monetary budget:

$\boldsymbol{M}=\boldsymbol{X}+\boldsymbol{c} . \boldsymbol{r} \ldots \ldots \ldots \ldots \ldots \ldots \ldots \ldots \ldots$ (2)

Where $\boldsymbol{X}=$ the quantity of numeraire whose price is one,

$\boldsymbol{r}=$ number of visits to the Fewa Lake,

$\boldsymbol{q}=$ environmental quality at the site,

$\boldsymbol{M}=$ exogenous income,

$\boldsymbol{c}=$ monetary cost of a trip,

It is assumed that $\boldsymbol{r}$ and $\boldsymbol{q}$ are (weak) complements and opportunity cost is controlled for this study. Maximizing equation (1) subject to the constraint of equation (2) yield the individual's demand functions for visits:

$$
\boldsymbol{r}=\boldsymbol{r}(\boldsymbol{P r}, M, q)
$$

Various independent variables were used to explain variation in the dependent variable $\boldsymbol{r}$. Both economic theory and the considerable experience of recreation managers have shown that demographic and other independent variables influence recreation visitation.

Demographic variables such as age, sex, education, income, marital status, rural versus urban residence and family size affect recreational demand. Intuitively it is assumed as age increases, participation decreases. It was expected that men would be more likely to participate than women. People with higher education were expected to appreciate outdoor nature-based activities more than people with less formal education. Household income is positively associated to the rate of lake visits while urban dwellers are likely to visit more than people from rural areas. Similarly, a better-quality park should attract an individual more often than a degraded-quality Lake. 
The model is specified as follows:

$$
\boldsymbol{r}_{i}=\boldsymbol{\beta}_{0}+\boldsymbol{\beta}_{1} T C+\boldsymbol{\beta}_{2} M I+\boldsymbol{\beta}_{3} \mathrm{AV}+\boldsymbol{\beta}_{4} \mathrm{VHLE}+\boldsymbol{\beta}_{5} H S+\boldsymbol{\beta}_{6} D_{1}+\boldsymbol{\beta}_{7} D_{2}+\boldsymbol{\beta}_{8} D_{3}+\boldsymbol{e}_{i}
$$

Where $\boldsymbol{r}_{\boldsymbol{i}}$ stands for the number of visits by the $\mathbf{i}^{\text {th }}$ individual to Lake per period of time, TC is the travel cost that refers round trip total cost from an individual's residence to and from the site. MI is the monthly income, AV the age of visitor, VHLE visitor's highest level of education, $H S$ refers size of the household, $D_{1}$ is dummy for sex, 1 if male and 0 otherwise, $D_{2}$ is dummy for location, 1 if urban dweller and 0 otherwise, $D_{3}$ is dummy for park quality, 1 if the visitor's perception about the site's recreational facilities is good and 0 if bad. The data entry and analysis was done in SPSS Version 16.

\section{RESULTS AND DISCUSSION}

The following table shows the demographic characters of the respondents. Most of the sampled respondents were fairly educated (secondary above) unmarried urban adult males among which a large proportion was engaged in salaried job or, run self proprietorship petty shops and earn a monthly income around ten thousand Nepalese rupees.

Table 1: Descriptive Analysis of Sample Respondents

\begin{tabular}{|c|c|c|}
\hline Variables & categories & $\mathrm{n}=\mathbf{5 0}$ \\
\hline Age (years) & & 33.08 \\
\hline Household size & & 5.46 \\
\hline \multirow[t]{2}{*}{ Sex } & Male & $82 \%$ \\
\hline & Female & $18 \%$ \\
\hline \multirow[t]{2}{*}{ Marital Status } & Unmarried & $62 \%$ \\
\hline & Married & $38 \%$ \\
\hline \multirow[t]{4}{*}{ Level of Education } & Illiterate & $16 \%$ \\
\hline & Primary & $18 \%$ \\
\hline & Secondary up to plus 2 & $22 \%$ \\
\hline & University level & $44 \%$ \\
\hline \multirow[t]{2}{*}{ Location } & Urban & $60 \%$ \\
\hline & Rural......................................... & $40 \%$ \\
\hline \multirow[t]{6}{*}{ Monthly income } & 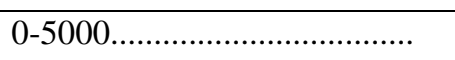 & $6 \%$ \\
\hline & 5000-10000........................... & $54 \%$ \\
\hline & 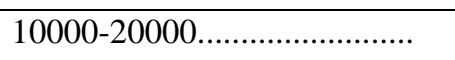 & $24 \%$ \\
\hline & $20000-30000 \ldots \ldots \ldots \ldots \ldots \ldots \ldots \ldots \ldots$ & $6 \%$ \\
\hline & 30000-50000......................... & $8 \%$ \\
\hline & 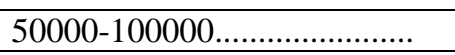 & $2 \%$ \\
\hline \multirow[t]{5}{*}{ Profession } & Agriculture/farming............... & $18 \%$ \\
\hline & Self proprietorship/retail shop. & $40 \%$ \\
\hline & Salaried job got private........ & $32 \%$ \\
\hline & Foreign employment................ & $4 \%$ \\
\hline & Unemployed............................ & $6 \%$ \\
\hline
\end{tabular}

Source: Field Survey, 2012. 
Recreational Demand for Fewa Lake.../57

\section{Regression Analysis}

First, the variables were tested for auto-correlation. According to Loomis and Walsh (1997), an absolute value of 0.8 indicates the possibility of multicollinearity. The correlation matrix displayed in Appendix 1 however shows no correlation higher than 0.46, which indicates that there is no multi-co linearity problem with data set. All variables could thus initially be included in the analysis. The adjusted R square value is around 40 percent.

Table 2: Estimated Result of Regression Equation

\begin{tabular}{|l|c|c|c|}
\hline Variables & Std. Coefficients & t-statistics & P value \\
\hline (Constant) & 3.456 & 5.127 & 0.000 \\
\hline Cost of travel*** & -0.350 & -2.842 & 0.007 \\
\hline monthly income*** & 0.357 & 2.688 & 0.010 \\
\hline Education*** & -0.455 & -3.161 & 0.003 \\
\hline Age ** & -0.378 & -2.630 & 0.012 \\
\hline household size & -0.368 & -0.922 & 0.362 \\
\hline Dummy1 Sex (Male=1) & 0.037 & 0.313 & 0.756 \\
\hline Dummy2 location**(Rural=1) & -0.277 & -2.171 & 0.036 \\
\hline Dummy3 visitors perception (good=1) & 0.190 & 1.542 & 0.131 \\
\hline Adjusted R & 0.40298 & & \\
\hline
\end{tabular}

Notes: * Significant at 10\% level; ** significant at 5\% level; *** significant at $1 \%$ level

As per the above table cost of travel, monthly income, education, age and location are statistically significant. The negative sign of coefficient of cost of travel implies that the higher the price paid by visitors to reach the lake, the lesser would be their frequency of visits. A unit increase in the cost of travel to the lake (price) would decrease the visitation rate (demand) by 0.35 times. Monthly income is positively related to rate of visitation of lake. If the income of consumer is raised by one unit then the rate of visit to the lake would increase around by 0.36 times. The coefficient of education does not have the expected sign. Age and visitation rate to the lake are negatively related. An increase in the age of the visitors by 1 year would decrease the rate of visitation to the lake by 0.378 times. Among the dummies, only location is significant. If the chance of visitors, residence being a rural, is 100 percent then the visitation rate would fall by around 30 per cent.

Recreational Value of Fewa Lake (consumer surplus)

Till date there is no any entry fee to Fewa Lake.

Table 3: Recreational Value of Fewa Lake in a Week of November, 2012

\begin{tabular}{|c|c|c|}
\hline Willingness to Pay [WTP] in NRs. & $\mathbf{n = 5 0}$ & Value \\
\hline 0 & $16 \%$ & 150 \\
\hline 15 & $20 \%$ & 520 \\
\hline 20 & $52 \%$ & 105 \\
\hline 35 & $6 \%$ & 150 \\
\hline 50 & $6 \%$ & 925 \\
\hline Total & 100 & CS = NRs. 18.5/person per visit \\
\hline
\end{tabular}

Source: Field survey, 2012 
The table above indicates that 84 per cent of the respondents are willing to pay for the improved condition of the lake. From the improved amenities of the lake, more than half of the respondents are willing to pay NRs. 20 as entry fee whereas 6 per cent of them are willing to pay NRs. 35 and NRs. 50. The consumer surplus (CS) is NRs. 18.5 /person for a trip to Fewa Lake among Nepali visitors.

\section{CONCLUSION}

From the study we may conclude that non-market valuation techniques can be used to estimate the economic benefits of environmental resources such as national parks, lakes and public parks. Most of the respondents in this study were adult unmarried, and higher secondary educated urbanites. The major determinants of recreational demand of Fewa Lake are travel cost, income of individuals, age, education and residential location. On the basis of consumer willingness to pay (WTP), the study infers that consumers are willing to pay an entry fee if Lake quality is well maintained and improved. The policy makers and stakeholders of such amenities have ample room for raising revenue for improving and conservation nature based sites.

\section{REFERENCES}

Bell, F.K. \& Leeworthy, V.R. (1990). Recreational demand by tourists for Saltwater Beach Days. Journal of Environmental Economics and Management, 18: 189-205.

Blackwell, B. (2007). The value of a recreational beach visit: an application to the Mooloolaba Beach and comparisons with other outdoor recreation sites. Economic Analysis \& Policy, 37(1): 77-98.

Clawson, M. \& J.L. Knetsch (1966). Economics of Outdoor Recreation. Washington D.C: John Hopkins University Press.

Clawson, M. (1959). Methods of measuring the demand for and value of outdoor Recreation, Reprint No. 10. Washington: Resources for the Future.

Freeman, A. M. (1993). The Measurement of Environmental and Resource Values: Theory and Methods. Washington D.C: Resources for the Future.

Garrod, G. \& K.G. Willis (1999). Economic Valuation of the Environment: Methods and Case Studies, Cheltenham, UK and Northampton, MA, USA: Edward Elgar.

Hotelling, H. (1947). The Economics of Public Recreation: The Prewitt Report. Washington D.C: National Park Services.

Kaosa-ard, M., D. P, T. Panayotou, \& J.R. Deshazo. (1995). Green Financing: Valuation and Financing of Khao Yai National Park in Thailand. Bangkok: Thailand Development Research Institute.

Khan, H. (2004). 'Demand for Eco-tourism: Estimating Recreational Benefits from the Margalla Hills National Park in Northern Pakistan'. SANDEE Working Paper No. 5-04. Kathmandu: South Asia Network for Development and Environmental Economics

Loomis, J.B. and R.G. Walsh (1997). Recreation Economic Decisions: Comparing Benefits and Costs. Venture Publishing, State College, PA.

Sarker, R. \& Surry, Y. (2004). The fast decay process in outdoor recreational activities and the use of alternative count data models. America Journal of Agricultural Economics, 86(3):701-715. 
Recreational Demand for Fewa Lake..../59

Shaw, D. \& Rogers, J. (2005). Review of non-market value estimation for festivals and events: $A$ Discussion Paper, Draft report submitted to the Ontario Tourism Board by Research Resolutions Ltd. Inc. Toronto.

Sohngen, B., Lichtkoppler, F. \& Bielen, M. (1999). The value of day trips to Lake Erie Beaches. Technical Bulletin TB-039. Columbus, OH: Ohio Sea Grant Extension.

Annex - I

Correlation Matrix

\begin{tabular}{|l|r|r|r|r|r|r|r|r|}
\hline & \multicolumn{1}{|c|}{ Sex } & \multicolumn{1}{c|}{ age } & \multicolumn{1}{c|}{$\begin{array}{c}\text { HH } \\
\text { size }\end{array}$} & Education & $\begin{array}{c}\text { Location } \\
\text { residence }\end{array}$ & $\begin{array}{c}\text { Monthly } \\
\text { Income }\end{array}$ & $\begin{array}{c}\text { Perception } \\
\text { of visitors }\end{array}$ & $\begin{array}{c}\text { Cost } \\
\text { of } \\
\text { travel }\end{array}$ \\
\hline Sex & 1.00 & -0.08 & -0.06 & 0.03 & -0.17 & 0.16 & -0.05 & 0.03 \\
\hline age & -0.08 & 1.00 & 0.13 & -0.47 & -0.13 & -0.06 & -0.15 & 0.05 \\
\hline HH size & -0.06 & 0.13 & 1.00 & -0.13 & -0.13 & -0.35 & -0.12 & -0.16 \\
\hline Education & 0.03 & -0.47 & -0.13 & 1.00 & 0.30 & 0.28 & -0.21 & 0.43 \\
\hline Location residence & -0.17 & -0.13 & -0.13 & 0.30 & 1.00 & 0.34 & 0.12 & 0.26 \\
\hline Monthly Income & 0.16 & -0.06 & -0.35 & 0.28 & 0.34 & 1.00 & 0.12 & 0.22 \\
\hline Perception of visitors & -0.05 & -0.15 & -0.12 & -0.21 & 0.12 & 0.12 & 1.00 & -0.24 \\
\hline Cost of travel & 0.03 & 0.05 & -0.16 & 0.43 & 0.26 & 0.22 & -0.24 & 1.00 \\
\hline
\end{tabular}

